\title{
Harper skirts transparency on foreign aid
}

$\mathrm{D}$ espite firmly emphasizing the need for full transparency on the effectiveness of international aid, Prime Minister Stephen Harper said the outcomes of $\$ 7.35$ billion investment in maternal- and childhealth aid will only be released with the consent of government contractors. "The government will be as transparent as we can possibly be," Harper told $C M A J$ at a May 30 press conference marking the conclusion of the maternal and child health summit in Toronto. But Harper stopped well short of pledging full transparency, citing contract restrictions.

Almost all Canadian international development projects are executed by contractors, including the World Bank, the World Health Organization and nongovernmental organizations such as Plan Canada. Asked why the government would not insist contractors be required to allow release of their outcome reports, Harper said that confidentiality stipulations restrict release of outcome data. "Obviously we always examine these numbers to ensure we are getting the results."

During the summit, United Nations Secretary-General Ban Ki-moon placed accountability for results as essential to saving lives, alongside financing, innovation and leadership.

Ironically, Harper has long championed transparency and accountability in his international maternal and child health campaign. Shortly after announcing Canada would invest an initial $\$ 1.1$ billion in 2010, he agreed to serve as co-chair with Jakaya Kikwete, president of the United Republic of Tanzania, on a Commission on Information and Accountability for Women's and Children's Health (COIA), established under UN auspices.

In 2011, the COIA released Keeping Promises, Measuring Results, a 31-page report calling for 10 reforms within startlingly short deadlines. For donor and recipient countries alike, the COIA

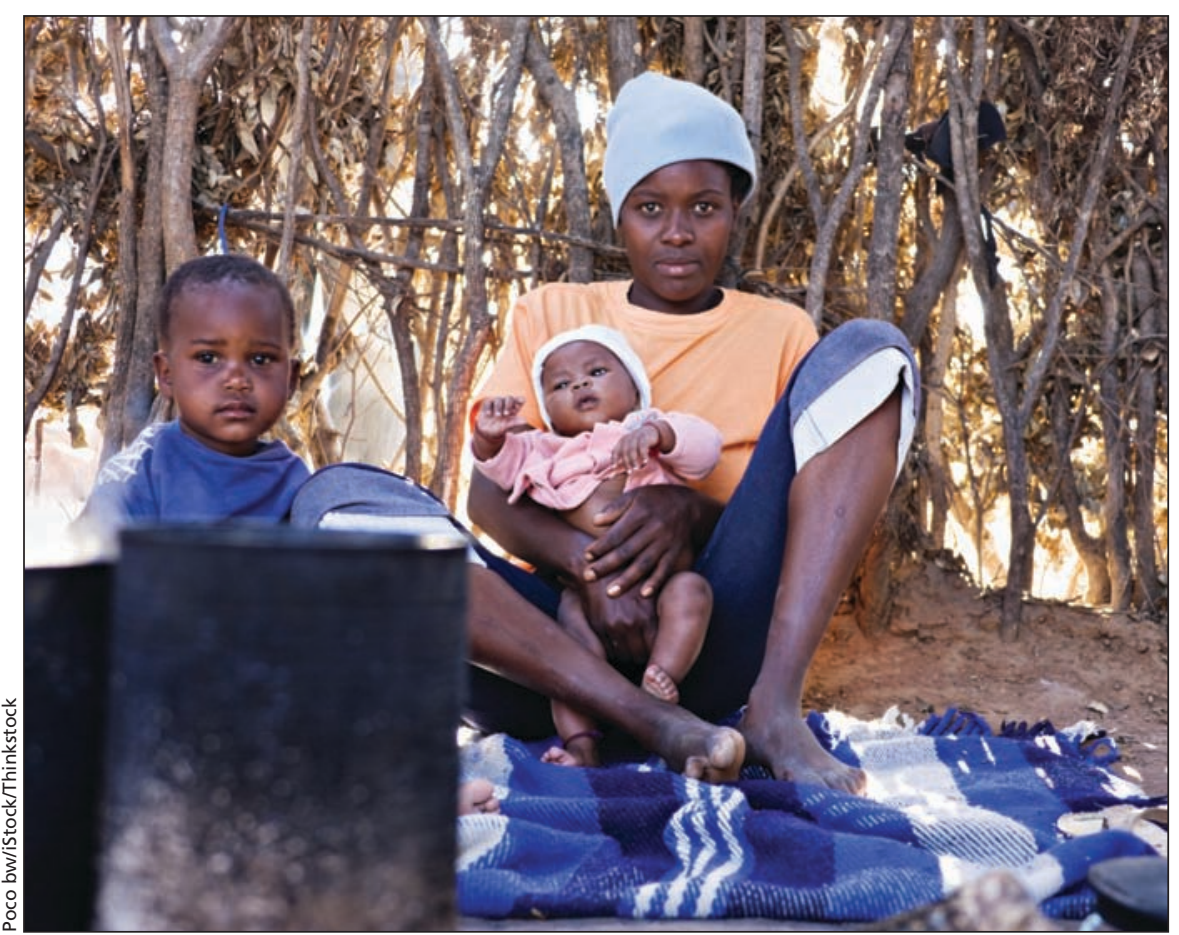

Despite co-chairing an international committee championing transparency in foreign aid, Prime Minister Stephen Harper's disclosure regarding Canada's investment is far from complete.

recommended that, by 2012 , "compacts" be written between governments and development agencies to report expenditures, and that all countries establish transparent "national accountability mechanisms." By 2013, the COIA wanted all stakeholders to be "publicly sharing information on commitments, resources provided and results achieved annually, at both national and international levels."

Informed by CMAJ that officials at Foreign Affairs Trade and Development Canada recently refused to release outcome reports from four maternal and child health projects in Haiti, Mozambique and South Sudan, Harper said the government was obligated to respect the privacy of contractors - in this case, UNICEF, the United Nations Office for Project Services and the World Health Organization.

Instead of providing UN outcome reports from these projects, government officials prepared statements, some of which guardedly indicate mixed results. "You've been given a great deal of information about the results on the ground," Harper said in defending the government's refusal to disclose the outcome reports.

In Ottawa, Jean-Francois Tardif, national coordinator for Global Poverty Solutions, a research group that studies Canadian aid commitments, says Canadian maternal and child health programs continue to suffer from a troubling lack of transparency, which he argues is crucial in helping measure results in the push to save the lives of women and children. "There is an issue of basic accountability in that I cannot reproduce the government's figures," Tardif charges. - Paul Christopher Webster, Toronto, Ont.

CMAJ 2014. DOI:10.1503/cmaj.109-4826 